\title{
EDITORIAL
}

\section{The Statute for an International Criminal Court and the United States: Peace Without Justice?}

Keywords: International Criminal Court; international criminal law; peacekeeping; statute.

\begin{abstract}
The adoption of the Statute of an International Criminal Court in July 1998 is widely regarded as a major step forward in international criminal law. The United States, however, does not share this point of view in all respects. It particularly fears that the Statute will allow prosecution of American peacekeepers for political instead of legal reasons. This article examines the provisions of the Statute in the light of that fear. It concludes that not only is such a fear unjustified, the United States position may have disastrous consequences for efforts in peacekeeping.
\end{abstract}

\section{INTRODUCTION}

Between 15 June and 17 July 1998, government representatives met in Rome to establish an International Criminal Court (ICC). The conference was the culmination of a process that started 50 years ago, when the United Nations General Assembly recognised the need for an international court to prosecute acts of genocide. ${ }^{1}$ After initial efforts toward the realisation of such a court in the 1950 s, the idea was put on hold, only to be revived in 1989. In that year, the General Assembly requested the International Law Commission (ILC) to resume work on the Court. ${ }^{2}$ In 1994, the ILC completed a draft Statute, ${ }^{3}$ which was subsequently reviewed by the General Assembly Ad Hoc Committee on the Establishment of an International Criminal Court and later by the Preparatory Committee on the Establishment of an International Criminal Court. The work of the ILC and these Committees constituted the point of departure of the Rome Conference.

After intense negotiations, the Conference finally adopted the Rome Statute of the International Criminal Court ${ }^{4}$ by a vote of 120 for, 7 against, and 21 ab-

1. By the adoption of the Convention on the Prevention and Punishment of the Crime of Genocide, General Assernbly Resolution 260 (III) of 9 December 1948, UN Doc. A/RES/260(III).

2. In General Assembly Resolution 39 of 4 December 1989, UN Doc. A/RES/44/39.

3. The text of the Draft Statute and the ILC's commentary are found in the Report of the International Law Commission on the Work of its Forty-Sixth Session, 49 UN GAOR Supp. (No. 10), UN Doc. A/49/10, paras. 23-91.

4. UN Doc. A/CONF.183/9 of 17 July 1998.

12 Leiden Journal of International Law 1-7 (1999)

(C) 1999 Kluwer Law International 
stentions. The United States (US) was one of the states that voted against ${ }^{5}$ and did not sign the Statute. ${ }^{6}$

One of the principal arguments given for the US rejection of the Statute concerned its implications for US peacekeepers. The Statute, it was asserted, would expose US peacekeepers to 'politicized' prosecution while the worst offenders of humanitarian law would be insulated. This article will examine this argument in the light of the Statute, leading to the conclusion that it does not fully justify the US reticence.

\section{THE ROLE OF THE US IN THE ESTABLISHMENT OF THE ICC}

The US was a driving force behind the establishment of the ad hoc Criminal Tribunals for the former Yugoslavia and Rwanda (ICTY and ICTR), generally seen as important steps leading up to the establishment of the ICC. It was similarly instrumental in the process leading up to the Rome Conference. Observers taking this as reflecting the potential role of the US during the negotiations concerning the Court's Statute were bitterly disappointed at Rome. The US adopted a very conservative attitude on a number of issues, opposing a Court with broad powers. As a result, it found itself opposed to a group of sixty-odd so-called 'like-minded states' working for a strong Court.

One of the principal arguments adduced by the US for its position was the fear that US soldiers participating in peacekeeping operations might be subjected to politicized prosecutions before the Court. ${ }^{7}$ The Pentagon actively opposed a broad mandate for the Court. Aspects of this policy were echoed in the efforts of the US delegation at Rome, a delegation which included a number of military experts. The Pentagon even invited foreign military attachés to attend briefings on US concerns about the Court. ${ }^{8}$

It may be noted that the Statute of the ICC does leave open the possibility that peacekeepers will be prosecuted by the international Court. Until now, jurisdiction in criminal matters was normally left to a peacekeeper's state of nationality. ${ }^{9}$ In the case of United Nations peacekeeping forces, this was explicitly provided for in agreements between the troop contributing states and the United Nations. In this light, international jurisdiction would be a new devel-

5. The vote was unrecorded. As a consequence, it is unclear which states voted against. China, Israel, and the United States stated so openly. Other states mentioned in this regard are Bahrain, India, Indonesia, Iraq, Libya, Qatar, and Yemen.

6. As of 10 December 1998, 64 states had signed the Statute.

7. See, e.g., the statement by Bill Richardson, United States Ambassador to the UN, to the Rome Conference. On the Internet: http://www.un.org/icc/speeches/617usa.htm.

8. See J. Lobe, Protests Over Pentagon Lobbying on ICC, Inter Press Service, 15 April 1998. On the Internet: http//www.ips/org/icc/background/backcinco.htm.

9. See, e.g., H. Risse, Das Verhältnis der UN-Truppen zu den Vereinten Nationen, zu den Entsende- und Aufnahmestaaten, in E. Koch (Ed.), Die Blauhelme im Einsatz für den Frieden 52, at 55 (1991). 
opment. The US, however, did not state that it was opposed to such jurisdiction in principle, but rather that because certain safeguards were not adequately provided, US troops would be vulnerable to politically motivated proceedings.

As it considered that such safeguards were not adequately provided for in the Statute as adopted at Rome, the US ultimately did not sign. Was this conclusion really justified by the Statute? To answer this question, it is necessary to take a closer look at key provisions of the Statute.

\section{ADMISSIBILITY}

The function of the new Court is expressly complementary to national courts. This means that the emphasis is on prosecution in national fora. A case is inadmissible before the ICC, unless a state which has jurisdiction over a particular crime is unwilling or unable genuinely to investigate or prosecute ${ }^{10}$ In contrast to the International Tribunals for the former Yugoslavia and Rwanda, it does not enjoy primacy over national courts and those courts are not obliged to defer to it when so requested.

The national criminal justice system of the US is certainly one of the most elaborate in the world, and according to some, also one of the best. In any event, the US has demonstrated in the past that in principle, it is not unwilling to prosecute its own peacekeepers for the crimes they commit. This is exactly what happened, for example, with US soldiers serving in the UN force in Somalia. ${ }^{11}$ If the US national criminal justice system continues to function effectively - and there is no reason to expect that it will not - there will be no need and no possibility to bring US soldiers before the Court at the Hague.

Further, the Statute provides states with a second chance to exercise national jurisdiction. Before a case is taken up by the ICC, the prosecutor will first notify all states parties as well as the states that would normally have jurisdiction, i.e. the state of nationality of the accused and the state on whose territory the crime was committed. ${ }^{12}$ Those states can then decide to initiate their own investigation, to which the prosecutor must defer. The exception to this rule is that on an application from the prosecutor following such a deferral, the pre-trial Chamber may authorise an investigation by the prosecutor.

The state that would normally have jurisdiction may also challenge the jurisdiction of the Court or the admissibility of a case before it prior to the commencement of a trial. ${ }^{13}$ The grounds for such a challenge are the same as

10. ICC Statute, supra note 4, Art. 17(1)(a).

11. See, e.g., R. Omaar \& A. de Waal, Somalia: Human Rights Abuses by United Nations Peace Forces $16(1993)$.

12. ICC Statute, supra note 4, Art. 18(1).

13. Id., Art. 19(2). 
those available to the Court when it considers jurisdiction and admissibility of its own accord. With regard to admissibility, these are the determination that a state which has investigated a case has been willing or able genuinely to prosecute, the principle of ne bis in idem and the determination that a particular case is not sufficiently grave for the Court to take up. ${ }^{14}$

\section{JURISDICTION RATIONE MATERIAE}

The Statute limits the jurisdiction of the Court to genocide, crimes against humanity, war crimes, and aggression..$^{15}$ Some aspects of the definitions of these crimes in the Statute go beyond existing definitions, while other aspects are more conservative.

The Statute's definition of genocide is certainly not ground-breaking. Indeed, it is restrictive by the very nature of the crime, which is particularly grave. It is not surprising then, that peacekeepers have never been indicted for this crime.

Only crimes which are "part of a widespread or systematic attack directed against any civilian population, with knowledge of the attack" fall within the jurisdiction of the Court as crimes against humanity. ${ }^{16}$ In addition, only the multiple commission of acts is covered, and an attack must be "pursuant to or in furtherance of a State or organisational policy". ${ }^{17}$ In this way, 'incidental' crimes which otherwise fall under the definition of crimes against humanity are excluded from jurisdiction, which constitutes an important limitation. Allegations against peacekeepers will most likely remain limited to incidents of this kind not falling within the jurisdiction of the Court. Past investigations have emphasized the isolated nature of crimes committed by peacekeepers. ${ }^{18}$

War crimes are covered by the ICC's jurisdiction "in particular when committed as a part of a plan or policy or as part of a large-scale commission of such crimes". ${ }^{19}$ This expression is again intended to underline that the Court's focus is not on incidents.

In addition, states parties can, after the Statute enters into force for those states, "opt out" on the Court's jurisdiction over war crimes for seven years. ${ }^{20}$ This provision was proposed by France. During the negotiations, the US

14. Id., Art. $17(1)$

15. Id., Art. 5

16. Id., Att. $7(1)$

17. Id., Art. 7(2)(a).

18. See, e.g., N. Lupi, Report by the Enquiry Commission on the Behaviour of Italian Peace-Keeping Troops in Somalia, 1 Yearbook of International Humanitarian Law 375, at 378.

19. ICC Statute, supra note 4, Art. 8(1).

20. Id., Art. 124. 
wanted a ten-year "opt out"-period for war crimes and crimes against humanity, which was rejected by the Conference.

Finally, the Court will only have jurisdiction over aggression once this crime has been defined and conditions for jurisdiction set out in accordance with the Statute by the states parties. ${ }^{21}$ This process promises to be an extremely long one, in view of the complex and time-consuming procedures provided for in the Statute and the controversies surrounding the definition of aggression.

In sum, the definitions of the crimes under the jurisdiction of the Court are not very broad. A number of elements make it unlikely that peacekeeper's conduct - which in the past has been limited to 'incidents' and will probably remain thus limited - will fall within the scope of those definitions.

\section{PROPIO MOTU PROSECUTOR}

One of the contentious issues at Rome was that of granting the Court's prosecutor the power to initiate investigations and seek indictments on his own initiative - propio motu. The US opposed such a power, arguing that if it were granted the prosecutor would become a "human rights ombudsman" and be flooded with complaints. ${ }^{22}$

Under the Statute, there is a propio motu prosecutor. His powers, however, are circumscribed by the Statute in a number of ways. First, as already noted, the Court and its prosecutor will only be concerned with the most serious crimes as defined in the Statute. In addition, a pre-trial Chamber of the Court, consisting of three judges, must first authorise any investigation by the prosecutor. It shall determine if there is a reasonable basis to proceed with an investigation, and whether the case appears to fall within the jurisdiction of the Court. ${ }^{23}$

If the US were to become a party to the Statute, it would also play a role in the selection of the prosecutor. In this way, the US could help ensure the appointment of an objective prosecutor not open to politically motivated indictments.

\section{SECURITY COUNCIL DEFERRAL}

The relationship between the Security Council and the Court was an important issue at the Rome Conference. The permanent members of the Council pleaded that the Court should not undermine the authority of that organ. Many other

21. Id., Art. 5(2).

22. See the Statement by Ambassador Richardson, supra note 7.

23. ICC Statute, supra note 4, Art. 15(4). 
states' positions, however, reflected their misgivings about the role the Council has played - or rather, failed to play - in the past with regard to the crimes with which the Court is concerned. They pointed, inter alia, at the poor performance of the Council with regard to the genocides perpetrated in Cambodia in the 1970s and in Rwanda in 1994. Their efforts somewhat reduced the room for manoeuvre left to the Security Council by the Statute, which were very broad in the ILC's draft statute. ${ }^{24}$ Under the Rome Statute, however, the Security Council can request deferral of an investigation or prosecution for a period of 12 months by a resolution under Chapter VII of the UN Charter. ${ }^{25}$ Such a request may be renewed under the same conditions. According to Article 27(3) of the Charter, such a decision by the Council requires the votes of nine members, including the five permanent members. As a result, no single permanent member of the Council - including the US - can block a case before the Court. Nevertheless, the arrangement still gives the Council an important position with regard to the Court. In the absence of a permanent member veto of the resolution calling for deferral, a case can be prevented from coming before the ICC. In this regard, it must be emphasized that not only American, but also British, French, and Russian soldiers are involved in a large number of peacekeeping activities, and that prosecution of US soldiers could constitute a precedent for others.

Finally, the US as the only remaining superpower has considerable influence in the Security Council. Other (permanent) members are unlikely to risk antagonising the US if they do not consider this absolutely necessary.

\section{CONCLUSION}

The US cannot be blamed for going to great lengths to keep its soldiers out of harms way - be it in the form of violence or politically motivated prosecutions by an international court. As the US points out again and again, it bears the lions share of the burden of international security. Its soldiers constitute the bulk of many peacekeeping operations. This - and anti-US sentiments in many areas makes US soldiers as well as civilians an attractive target. Attacks on US embassies in 1998 have made this clear once again.

It is another thing, however, to assume automatically that the Court's Statute will be prejudicial to US peacekeepers' interests. In the first place, the Statute contains a number of safeguards against frivolous prosecutions. In the light of the provisions on admissibility, jurisdiction ratione materiae, the powers of the prosecutor, and Security Council deferral discussed above, the prosecution of a US soldier for a war crime is no more than a theoretical possibility. In the second place, the ICC's purpose is to prosecute exactly those who would stand in

24. See 1994 ILC Draft Statute, supra note 3, Art. 23.

25. ICC Statute, supra note 4, Art. 16. 
the way of peace and security; the Karadžićs, Pol Pots, and Saddam Husseins of this world. It is they who pose the greatest threat to peacekeepers, not the Court. The Court is the peacekeepers ally, not their antagonist.

Finally, no matter what 'international responsibilities' the US has, it cannot be held to different standards than other states. As the former prosecutor of the ICTY, Richard Goldstone, pointed out, it could appear that what the US is saying is, "in order to be peacekeepers [...] we have to commit war crimes" ${ }^{26}$ Such an argument, which undermines the fundamental values subscribed to by the US as well as the United Nations, cannot be accepted.

In this light, the decision by the US not to sign the Statute must be regretted. All the more so, because it might have serious consequences for the functioning of the Court. The US supported and continues to support the ad hoc Tribunals for the former Yugoslavia and Rwanda financially, in terms of personnel as well as politically. Much of what has been achieved by those tribunals would not have been possible without US commitment. It is precisely this commitment which the ICC will lack. ${ }^{27}$ Even more ominous is the statement by the US state department that it will "actively oppose" the Court. ${ }^{28}$ The Statute of the ICC has met with particular resistance in the US Senate Foreign Relations Committee, the chairman of which has stated that the US must fight this treaty. In addition, he has announced far-reaching measures, including a promise to seek assurances from Secretary of State Madeleine Albright that US soldiers will not participate in NATO or UN operations until allies agree that the troops would not be subject to the Court's jurisdiction. ${ }^{29}$ In practical terms, not only do these measures affect the Court, they also constitute the pronouncement of a death sentence on the current system of peacekeeping.

Several years ago, one commentator remarked that in contrast to the US:

there are other states, not so easily classified, which may be strongly disinclined to support the establishment of an effective International Criminal Court. If such nations are permitted to participate fully in the development of a treaty creating such a court, they may simply work to weaken the court as much as possible, then refuse to join the treaty regardless of how much the court has been weakened. ${ }^{30}$

Ironically, the statement now appears to apply to the US itself.

Marten Zwanenburg

26. US Stance Contradictory, Former UN Prosecutor Says, International Press Service, 17 June 1998.

27. See Statement of Ambassador D. Scheffer to the Sixth Committee of the United Nations General Assembly of 21 October 1998.

28. Press Conference with Ambassador D. Scheffer, Head of the US delegation in Rome, at the Foreign Press Center, Washington D.C, 31 July 1998.

29. J. Schuman, Senators Fight War Crimes Treaty, Associated Press News Release, 23 July 1998.

30. D.H. Derby, An International Criminal Court for the Future, 5 Transnational Law \& Contemporary Problems 307, at 315 (1995). 